\title{
Sylvie Vielledent, 1830 aux théâtres
}

\section{Lise Sabourin}

\section{(Q) OpenEdition}

\section{Journals}

\section{Édition électronique}

URL : http://journals.openedition.org/studifrancesi/6316

DOI : 10.4000/studifrancesi.6316

ISSN : 2427-5856

\section{Éditeur}

Rosenberg \& Sellier

\section{Édition imprimée}

Date de publication : 1 novembre 2010

Pagination : 560-561

ISSN : 0039-2944

\section{Référence électronique}

Lise Sabourin, «Sylvie Vielledent, 1830 aux théâtres », Studi Francesi [En ligne], 162 (LIV | III) | 2010, mis en ligne le 30 novembre 2015, consulté le 11 janvier 2021. URL : http://journals.openedition.org/ studifrancesi/6316 ; DOI : https://doi.org/10.4000/studifrancesi.6316

\section{Ce document a été généré automatiquement le 11 janvier 2021.}

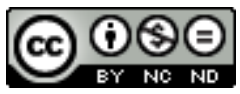

Studi Francesi è distribuita con Licenza Creative Commons Attribuzione - Non commerciale - Non opere derivate 4.0 Internazionale. 


\title{
Sylvie Vielledent, 1830 aux théâtres
}

\author{
Lise Sabourin
}

\section{RÉFÉRENCE}

SYLVIE VIELLEDENT, 1830 aux théâtres, Paris, Honoré Champion, «Romantisme et modernités», 2009, pp. 669.

1 Choisissant pour corpus les pièces créées, publiées ou reprises avec remaniement (et même quelques-unes restées manuscrites) durant l'année civile 1830, cet ouvrage se propose de montrer comment la liberté artistique lancée par la bataille d'Hernani s'est manifestée en liberté politique du théâtre après les Journées de juillet. Renonçant (ou du moins la portant au second plan de ses futurs chapitres) à une étude par formes théâtrales, Sylvie Vielledent dégage des séries qu'elle discerne au fil des mois quatre thèmes: un littéraire, sur les parodies d'Hernani; trois plus historiques, la représentation des barricades, des jésuites et de Napoléon.

2 Les parodies d'Hernani reflètent les critiques du temps sur sa proximité avec la structure mélodramatique, en dénonçant les invraisemblances d'intrigue; elles dérivent en burlesque le grotesque hugolien, elles en dégradent le sublime par la transposition en personnages populaires (marchands, métiers ambulants, pègre). Leur statut, moins visé par la censure, n'en fait pas pour autant des défenses de l'héritage classique, présent en filigrane, mais contaminé par des allusions à l'actualité de l'affrontement entre «cafards» à perruques et «camarades» romantiques. Cette «littérature de l'entredeux», tout en pratiquant la dérision, constitue un gage d'estime envers les pièces à succès qu'elle démarque.

3 Après l'abolition de la censure, les pièces représentées dans la seconde moitié de l'année tentent d'abord de représenter sur scène les Trois Jours: au peuple qui a vécu en action les barricades, il est difficile de donner maintenant un spectacle qui en rende l'émotion. Aussi les auteurs recourent-ils à des recettes déjà éprouvées après la Révolution française: le récit est délégué à un témoin visuel qui informe les provinciaux des nouvelles de la capitale, avec les effets de suspense et de surprise qu'offre le retard 
de l'information. Pour le spectaculaire sont bien utiles les petits faits vrais ou les paroles authentiques mises en dialogue (marquées d'un «historique» qui relègue quasiment la fiction au reportage), les effets de tableau d'une foule costumée sur scène (la description en didascalie les remplaçant dans le théatre à lire). Le parallèle avec 1789 fait réfléchir: et l'on félicite le peuple d'avoir su par les Trois Glorieuses proscrire les Bourbons sans aboutir aux horreurs de 1793-94. Il est frappant de noter combien le théâtre, école populaire de révolution en ces circonstances, assume des fonctions de dénonciation et de caricature proches de celles de la presse. Le bouffon et le sublime s'exercent dans une vision simplificatrice stigmatisant les puissants d'Ancien Régime et louant les émeutiers (prolétaires, élèves de Polytechnique); malgré l'amertume de voir peu accompli le rêve ouvrier et ouverte la chasse aux sinécures, le roi des Français, présenté comme fort bonhomme, paraît un rempart nécessaire contre un complot contre-révolutionnaire susceptible de renaître.

4 L'anticléricalisme libéral se déchaîne contre ses bêtes «noires», les Jésuites. Les chapitres de Stendhal concernant leur pouvoir sous la Restauration trouvent des échos multiples, qui reprennent aussi une vieille veine française sur la truculence et la lubricité des moines, l'hypocrisie pateline, la vénalité née d'un désir de revanche sociale, le goût de la manipulation habituellement associée à la congrégation. En contrepoint est exalté le bon curé proche de ses ouailles, car il faut maintenir le respect envers la religion, élévatrice de l'âme et socle moral de l'édifice social. Poncifs mélodramatiques, frivolité de vaudevilles, veine farcesque concourent pour rendre le langage cafard, le ton inspiré des faux dévots, mais aussi moderniser les reprises de pièces révolutionnaires.

5 Sort seul triomphateur Napoléon: l'homme à la redingote grise et au petit chapeau, réputé frugal et travailleur, proche du peuple en vrai père de la nation, chef de famille respecté (la «bonne Joséphine» et le malheureux fils évacuant de la légende le divorce et Marie-Louise) est en effet une figure bien commode qui convient au peuple. Garant de l'ordre domestique comme public, il est un héros épique, modèle d'ascension sociale, que Sainte-Hélène fait accéder à un martyre quasi christique. Restitution de batailles, exaltation tragique de la clémence d'un empereur, réservoir d'images et d'historiettes, le mythe napoléonien est propice à l'illusion théâtrale: on admire la performance d'acteurs avides de ressemblance avec le grand homme; la caution historique semble donnée par l'insertion anticipée du retour des cendres, fournissant une conclusion apologétique à cette destinée d'exception. La chanson ou la peinture contemporaines sont abondamment utilisées pour référence. Ainsi s'élabore, face aux ennemis publics, un théâtre de la réconciliation s'ancrant dans l'héritier de la Révolution, dont on oublie le despotisme, au profit d'une union nationale bien nécessaire après les troubles récents. La liberté offerte par l'abolition de la censure incite les auteurs pressés de s'insérer dans l'actualité à porter les couleurs du nouveau gouvernement avant les réveils amers de 1831-32.

6 Le corpus original de cet ouvrage, qui le cite abondamment, fait son intérêt, même si l'on peut déplorer une certaine confusion dans la conduite de la pensée, nourrie d'une riche bibliographie, mais ne semblant pas prendre assez de recul par rapport à sa riche enquête. 